ELORE (ISSN 1456-3010), vol. 17 - 2/2010.

Julkaisija: Suomen Kansantietouden Tutkijain Seura ry.

[http://www.elore.fi/arkisto/2_10/fingerross_2_10.pdf]

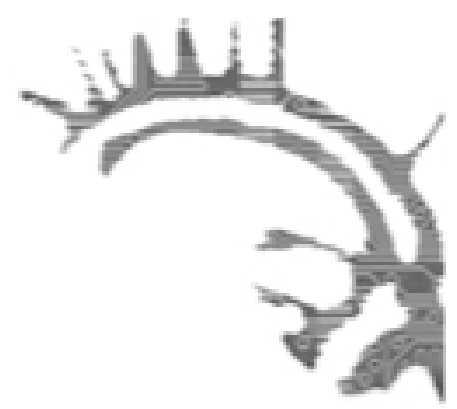

KIRJA-ARVIO

\title{
HYÖDYLLINEN OPAS TIETOKIRJOITTAJILLE
}

MERTANEN, VIRVE 2007: Tietokirjoittajan käsikirja. Tampere: Vastapaino. 167 sivua.

\section{$\underline{\text { Outi Fingerroos }}$}

Tietokirjallisuutta on kaikki mikä ei ole kaunokirjallisuutta, ja vieläpä siten, että lasten tietokirjat luokitellaan kaunokirjallisuudeksi. Tietokirjoja ovat niin väitöskirjat kuin keittokirjat, komiteamietinnöt kuin kokoamisoppaat. Tietokirjoja yhdistää se, että ne eivät perustu pelkkään mielikuvitukseen. (Mertanen 2007, 9.)

Virve Mertasen Tietokirjoittajan käsikirja on opas kaikille sellaisille kirjantekijöille ja asiantuntijoille, joiden on saatava viestinsä perille muidenkin ymmärtämässä muodossa. Opas on tarpeellinen sekä ensikertalaiselle että pidemmälle ehtineelle tieteen tekijälle, koska molemmilta keskimäärin puuttuu rutiini yleistajuiseen kielen ilmaisukeinojen käyttöön. Virve Mertanen on kokenut tietokirjoittamisen ammattilainen, sillä hän on työskennellyt kustannusalalla 20 vuotta kirjojen, lehtien ja niiden markkinoinnin parissa.

Opas koostuu seitsemästä pääluvusta, joissa käydään läpi tietokirjan tekoprosessi, hyvän tekstin tunnuspiirteet, ulkoasun suunnittelu, käsikirjoituksen viimeistely, tekijänoikeuskysymykset ja kustannustoiminta. Kirjan liitteet ovat erityisen hyviä, sillä sinne on koottu kirjoittajan muistilista, oikeinkirjoitusohjeet, ammattilaisten käyttämät korjausmerkit ja ohjeet kustannussopimukselle, kirjarojalteille ja muille palkkioille. Erittäin hyödyllinen apuväline on ammattisanasto, jossa esitellään tietokirjoittamiseen liittyvät monimutkaiset termit A3-arkista värillisyystietoa kuvaaviin erilaisiin mittausmenetelmiin. 
Outi Fingerroos: Hyödyllinen opas tietokirjoittajille

\section{HYVÄ TIETOKIRJA LUKIJAA VARTEN}

Mertasen kokemus kustannusalalta on, että tietokirjoittajat eivät ole seppiä syntyessään mutta voivat sellaisiksi harjaantua. Mertanen tasapäistääkin kaikki tietokirjantekijät kertoessaan heti kirjansa alussa, miten tietokirjan tekoprosessi alkaa asiakkaasta eli oletetusta lukijasta ja myös loppuu asiakkaaseen eli kirjan lukijaan. Hänen mielestään on jopa sama, mitä joku paperille laittaa ja miten, jos kirjoittamisen prosessissa ei huomioi tietokirjoittamista muille kirjoittamisena. "Kun kirjan pitää voittaa kilpailu lukijan ajasta ja mielenkiinnosta, kirjoittaja ei voi ajatella, että lukija selviää tekstistä, koska asia on niin tärkeä (s. 13).”

Lukijan palveluun kietoutuu itsestään selvästi hyvä teksti, jonka tunnuspiirteistä tärkeimmät ovat loogisuus ja virheettömyys. Tietokirjan on oltava rakenteeltaan sellainen, että lukija jaksaa kahlata sen alusta loppuun asti. Mertasen mukaan selkeästi ajateltua on helppo kirjoittaa ja kielenhuolto tekee tekstistä myös helppolukuisen. Mertanen kertookin Anto Leikolan sanoneen, että tietokirjan ikä on lyhyt, koska tieto vanhenee nopeasti. Silti hyviä tietokirjoja luetaan satojenkin vuosien kuluttua, mutta ei vanhentuneen tiedon vaan hyvän tekstin vuoksi.

\section{APUA KÄYTÄNNÖN ONGELMIIN}

Mertanen tarjoaa lukemattomia työvälineitä tietokirjoittajan avuksi. Hän kertoo, miten asioiden pitäisi olla. Tietokirjan teksti, tyyli ja esitystapa tulee sovittaa lukijan tarpeisiin. Tekstissä tärkeät asiat sijoitetaan lukujen ja kappaleiden alkuun tai loppuun. Kirjan tärkeimpään asiaan on päästävä ennen puoltaväliä. Kuvat, kaaviot ja taittotekniset korostukset suunnitellaan lukijaa varten. Lyhyitä pää- ja sivulauseita on hyvä suosia, mutta lauseenvastikkeita kannattaa välttää. Kerro, kuvaa ja käy dialogia!

Mertasen kirjan parasta antia ovat selvitykset hyvinkin yksinkertaisilta vaikuttavista asioista, kuten siitä, mikä on esipuheen ja johdannon välinen ero tai miksi kirjassa on nimiösivu, välilehtiä, liitteitä ja erilaisia hakemistoja, joiksi lasketaan myös sisällysluettelo ja kirjallisuuslähteet. Se, että esipuhe on kirjan lukijalle suunnattu "myyntipuhe", ei tietokirjoittajille monesti ole selvillä - siksi sille myös kannattaisi antaa esipuhetta omaperäisempi otsikko. Esipuhe on kirjan olemassaolon perustelu: "Esipuhe myy lukijalle kirjan perusajatuksen, ja johdantoluku vie lukijan aiheeseen seikkaperäisemmin.” Tiivistelmä taas on tutkimuksen sisällön kuvausta varten. 
Outi Fingerroos: Hyödyllinen opas tietokirjoittajille

\section{KÄSIKIRJOITUS VALMISTUU HITAASTI}

Tietokirjoittajan käsikirjan luku 4 "Käsikirjoituksen tekniset vaatimukset" pitäisi sisällyttää jokaisen tohtorikoulutettavan, yliopistotutkijan, lehtorin ja professorin pakolliseen lukemistoon. Moni kirjoittaja nimittäin säästyisi paljolta vaivalta, jos hän sopisi käsikirjoituksen teknisistä vaatimuksista etukäteen kustannustoimittajansa kanssa. Koska tätä keskustelua käydään usein vasta tekoprosessin loppuvaiheessa, esittää Mertanen kirjassaan ne perusasiat, jotka pätevät yleisesti kustantamosta toiseen.

Mertasen tekstintekijälle antamista ohjeista tärkein on se, että käsikirjoitus kirjoitetaan niin sanottuna raakatekstinä, vailla tekstinkäsittelyn hienouksia. Kustannustoimittajan ja taittajan toiveena on saada käsikirjoitus, jossa ei ole tavutuksia, sivuasetuksia, versaaleja eli suuraakkosia, ristiviittauksia, ylä- ja alaviittauksia tai tekstinkäsittelyllä tehtyjä, valmiiksi asemoituja taulukoita. Hyvästä nyrkkisäännöstä käy se, että teksti kirjoitetaan 12 pistekoon kirjasimella rivivälillä 1,5 tai 2. Kappaleet erotetaan toisistaan rivinvaihdolla. Välimerkkien teossa olisi hyvä totutella ascii-koodistoon (yleisimmät koodit löytyvät kirjan sivulta 80). Lisäksi kaikki leipätekstistä erotettava aines, kuten sisennykset, korosteet, anfangit, lainaukset, otsikot, kuvatekstit ja alaviitteet tulee merkitä huolella. Kuvat ja taulukot tallennetaan erillisinä tiedostoina - niitä ei missään nimessä sijoitella valmiiksi tekstin lomaan.

Mertanen kertoo kirjassaan seikkaperäisesti myös kustantajan kanssa tehtävästä työstä, sillä kustantaja on tietokirjoittajan merkittävin työkumppani prosessin loppuvaiheessa. Tietokirjoittajan on aina varauduttava siihen, että kirjan matka käsikirjoituksesta lukijan käteen on pitkä, kenties kivinenkin taival. Kustantaja vastaa kaikesta käsikirjoituksen jälkeisestä työstä: taloudesta, teknisestä toteutuksesta ja markkinoinnista. Kustantajalle luovutettu käsikirjoitus ei ole juuri koskaan valmis sellaisenaan taitettavaksi ja julkaistavaksi.

Taitava tietokirjoittaja saattaa myydä ideansa suomalaisten kirjamarkkinoiden suurille kustantajille (Sanoma-WSOY, Otava ja Kustannusosakeyhtiö Tammi), jotka tavoittelevat kirjamyynnillään selkeästi tulosta ja näkyvyyttä. Koska päätaloja ei tietokirjapuolella synny, keskisuurten ja erikoistuneiden tietokirjakustantajien riveistä löytyy huomattavasti laajempi joukko tietokirjoittajia. Erilaisten taustayhteisöjen sarjat täydentävät tietokirjoittamisen kenttää erikoisjulkaisuillaan.

\section{KiRJA KAIKILLE TIETOKIRJOITTAJILLE}

Tietokirjoittajan käsikirja on kauttaaltaan hyvällä ja napakalla kielellä kirjoitettu. Kirjan lukeminen on suorastaan vaivatonta, sillä kahlasin sen kannesta kanteen junamatkalla Helsingistä Jyväskylään. Virve Mertanen on onnistunut ennen kaikkea siinä, että teos pysyy käytännönläheisen opaskirjan mittapuussa mutta tarjoaa tieto- 
Outi Fingerroos: Hyödyllinen opas tietokirjoittajille

kirjailijalle kuitenkin kaiken sen tiedon, mitä hän kirjaa tehdessään tarvitsee.

Pidän siitä, että Mertanen ei ole lähtenyt kosiskelemaan ostajia myyvällä oppaalla, jossa on upea kuvitus, kovat kannet ja pääomavaltainen yleiskustantamo taustavoimana. Sen sijaan kirja on tehty tietokirjoittajille työvälineeksi lämpimällä sydämellä. Tulen suosittelemaan kirjaa kaikille tohtoriopiskelijoille ja ohjattavilleni; toimitustyötä tekeville kirja on suorastaan pakollista luettavaa.

Dosentti Outi Fingerroos on yliopistotutkija Jyväskylän yliopiston Monikulttuurisuus ja vuorovaikutus -osaamiskeskuksessa. 